\title{
UNDERGRADUATE STUDENTS' MOTIVATIONS FOR THE CONSUMPTION OF LEGAL DRUGS
}

\author{
Verónica Margarita Hernández Rodríguez ${ }^{1}$
}

Zeyne Alves Pires Scherer ${ }^{2}$

Hernández Rodríguez VM, Scherer ZAP. Undergraduate students' motivations for the consumption of legal drugs. Rev Latino-am Enfermagem 2008 maio-junho; 16(especial):572-6.

This qualitative research aimed at identifying conceptions held by undergraduate students regarding the term motivation, and motives leading them to the consumption of legal drugs. Data were collected through a questionnaire with four open questions, applied to 15 students of a public university in the central region of Mexico. In order to perform the data analysis, answers were classified in two categories: a) Undergraduate students' conceptions regarding the term motivation and b) Undergraduate students' conceptions regarding the motives for consumption. Such analysis indicated that students identify two types of motivations: external and internal. The external motivation includes family, mass media and friends; whereas internal motivation includes personal characteristics, need of belonging, curiosity, pleasure and idleness.

DESCRIPTORS: motivation; student; students, nursing

\section{MOTIVACIONES DEL ESTUDIANTE UNIVERSITARIO PARA EL CONSUMO DE DROGAS LEGALES}

La presente investigación cualitativa buscó identificar las concepciones que tiene el estudiante universitario sobre el término de motivación y los motivos que les llevan al consumo de drogas legales. Se realizó la recolección de datos mediante la aplicación de un cuestionario de cuatro reactivos a quince estudiantes universitarios inscritos en una universidad pública de la región centro del México. El análisis de resultados se hizo a través de la categorización de respuestas en dos categorías: a) Concepciones del estudiante sobre el término motivación b) Concepciones de los estudiantes sobre los motivos para el consumo. Se obtuvo como resultados que los estudiantes identifican dos tipos de motivaciones, la externa y la interna. Las motivaciones externas incluyen la familia, los medios de comunicación y los amigos, mientras que la motivación interna incluye las características personales, necesidad de pertenencia, curiosidad, placer y ociosidad.

DESCRIPTORES: motivación; estudiante; estudiantes de enfermería

\section{MOTIVAÇÃO DO ESTUDANTE UNIVERSITÁRIO PARA O CONSUMO DE DROGAS LEGAIS}

A presente pesquisa qualitativa procurou identificar a concepção do estudante universitário sobre o termo motivação, e as razões que o levam ao consumo de drogas legais. Para tanto, a coleta de dados foi realizada através da aplicação de um questionário, com quatro perguntas abertas, a quinze estudantes universitários matriculados em uma universidade pública da região central do México. $A$ análise dos resultados foi feita através da categorização das respostas em dois grupos: a) Concepção dos estudantes sobre motivação; b) Concepção dos estudantes sobre os motivos para o consumo. Os resultados mostraram que os estudantes identificaram dois tipos de motivações: a motivação externa e a motivação interna. Entre as motivações externas, incluem-se a família, os meios de comunicação e os amigos. Enquanto as motivações internas incluem características pessoais, necessidade de pertença, curiosidade, prazer e ociosidade.

DESCRITORES: motivação; estudante; estudantes de enfermagem

\footnotetext{
${ }^{1}$ RN, Faculty and Registrar at the University Autonoma of Querétaro, School of Nursing, Mexico, e-mail: covetojo@yahoo.com; ${ }^{2}$ RN, Faculty, University of São Paulo at Ribeirao Preto, College of Nursing, WHO Collaborating Centre for Nursing Research Development, Brazil, e-mail: scherer@eerp.usp.br
} 


\section{INTRODUCTION}

Substance consumption is not a new phenomenon. It has been observed since Pre-Hispanic cultures, when people already used addictive plants, with religious, ceremonial and medical connotations. They also used herbs, concoctions and several medicines for self-treatment and self-care ${ }^{(1)}$.

Nowadays, the consumption of "Drugs"(2) (any substance that, as inserted to the body, changes the natural operation of the nervous central system of the subject, besides, it is likely to generate psychological or physical dependence, or both), which are considered legal (alcohol and tobacco) and illegal (marihuana, opium, cocaine, hallucinogens, heroine, etc.), is a national and international public health problem, which generates great expenses in economic, social, political and moral matters, for all consuming communities ${ }^{(3)}$.

International epidemiological studies show that the consumption of this kind of substance is increasing. In Great Britain, around 100,000 inhabitants have already used heroine ${ }^{(4)}$. The national consumption rates in Chile for all socioeconomic levels are at $11 \%$ for women and $17 \%$ for men, identifying alcohol (70\%) as the most consumed drug, followed by marihuana (16.3\%). It is worth stressing that one out of two undergraduate students is a smoker, a fact mostly detected in high socioeconomic levels ${ }^{(5)}$.

The 2002 Mexican National Addictions Questionnaire (Encuesta Nacional de Adiciones del 2002 - ENA-2002) reported that 2,862,448 people in the population range from 18 to 29 years old smoke everyday. In this group, $35.1 \%$ are secondary and $26.9 \%$ college students ${ }^{(6)}$. Likewise, it also states that $52.5 \%$ of the population consumes alcohol on a daily basis, whereas $18.7 \%$ are ex-consumers ${ }^{(6)}$.

In this context, there are several models, paradigms and theories to explain the drugs phenomenon, opening a wide range of options to obtain a comprehensive view of the problem and explanations based on several epistemological conceptions(7). However, many epistemological $^{(7)}$ conceptions only focus on a few age groups, and a large variety of studies has been developed for adolescents. For the group of people from 18 to 25 years old, on the other hand, the development and implementation of programs and projects for drug use prevention are only proposed for this kind of student and the rest of society ${ }^{(5)}$.

Different authors have defined the concept of motivation as something closely related to social relations; since the motives that guide one's behavior are taken either from relations with other people ${ }^{(8)}$, or from the way that event (behavior) is observed, inferring past events and their consequences ${ }^{(9)}$.

Regarding the differences between intrinsic and extrinsic motivation: the first kind of motivation arises when the subject performs an activity just for doing it. On the other hand, the subject experiences extrinsic motivation, derived from the environment, when performing an activity to attend to a motive that is not related to the activity itself $f^{(9)}$.

\section{OBJECTIVES}

This study aims to identify how undergraduate students conceive the term motivation and name the motives that lead them to the consumption of legal drugs. This objective was proposed considering connotations of the term "motivation" according to collective and individual perspectives and behaviors.

\section{METHODOLOGY}

The present research is carried out through the qualitative method. This research perspective aims at capturing the essence or origin of the experiences lived by the subjects involved in the phenomenon whose perception is being studied ${ }^{(10)}$, so as to subsequently describe these experiences and give them meaning ${ }^{(11)}$.

Considering the above, it should be acknowledged that the research results cannot be generalized $^{(10)}$, as data is collected from the subject who experienced the events. By admitting that each individual is singular and unique, it can be assumed that individuality cannot be equalitarian and applicable to groups or masses of individuals, who live in social, historical and cultural contexts that are specific and different from other people ${ }^{(12)}$. It should be considered that perceptions differ for each person and change over time ${ }^{(11)}$.

In this context, a questionnaire was applied . This questionnaire presented four questions to fifteen students enrolled in a public university from the central region of Mexico, who spontaneously and freely decided to participate in the research.

Before starting data collection, authorization was requested from the corresponding instances, so that the research could be developed in their facilities. As soon as a positive answer was received, possible 
participants (undergraduate students) received explanations about the research, its topic and objectives.

After this stage and after doubts and questions had been clarified, the Informed Consent Term was read, so as to guarantee respect for research ethics, as established by the General Health Law for Health Research Matters. Later on, people who agreed to be included into the research received the Informed Consent Term and the semi-structured interview instrument, so that it could be answered in a free, autonomous and sincere way.

Repetitive reading of data was necessary for the sake of analysis, in order to get more familiar and thus start an intensive analysis. ${ }^{(13)}$

The study was then continued with a constant comparison of the interviews and answers given, in order to analyze the saturation level, group the interviewsaccording to the similarities identified, and finally start and consolidate the result categories ${ }^{(13)}$.

\section{RESULTS}

The results of this study are reported through two categories detected while processing data:

Undergraduate student's conceptions on motivation

According to the undergraduate students' statements, two motivations can be observed: internal and external. They can be present in the same statement, like in the following, talking about motivation: They are the incentive we have to do different things everyday. This incentive may be either external, according to daily contributions, or internal, according to what the subjects think and their will to do things (Alondra).

Nevertheless, most of the answers identified only one kind of motivation, highlighting the external kind: The ways in which a person does something (Laura). Incentive that encourages you to do something you did not know and calls your attention (Yolanda). It is what inspires me to do things. It is what leads you to do something (Montserrat). Something that encourages the subject to do things that he does not do by himself. (Daniela).

Undergraduate students' conceptions on motives for consumption

Three conceptions that generate motives for the consumption of legal drugs were identified in the external motivation: family, means of communication and friends, among which the family predominated.
Intrafamiliar problems, dysfunctions or disintegration of the family and the use of substances at home were identified in the family conception. Conflicts with the family (dysfunctional), personal problems (low self-esteem, complexes and phobias), frequent imitation (the person who imitates another's behaviors), and means of communication lead to a superficial life that includes fashion and drugs (Raúl).

Through the participants' statements, it could also be identified that the motivations which tend to the consumption of drugs came from several sources, such as personal problems, need to belong to a group, curiosity, pleasure and idleness. The need to belong predominated among other factors, followed by personal problems and curiosity, with smaller proportions, even though the three sources were mentioned by almost the same number of participants. I think there are many factors, as the person who consumes drugs does it for different reasons, such as to feel integrated in a group of people, to hide or forget a problem for a moment, because he is not sure of what he wants, and does not have things to do (Alondra).

The need to belong reveals the pursuit of integration and acceptance, including the imitation of group behaviors to promote oneself. With regard to their personal problems, the students mention low self-esteem, complexes or phobias, problems in general and loneliness, which is the most frequently mentioned in this case. One subject's statement complements about the reason why students are possibly giving importance to personal characteristics: I believe the friends, family influences, means of communication (advertising) and the need to feel accepted, as well as the low self-esteem are the point, after all, people who accept themselves the way they are and are self-confident do not harm their body, making it work under the effects of alcohol and tobacco (Jenny).

In the Table 1 can bee the distribution of motivations for consuption of legal drugs among undergraduate studants.

Table 1 - Indicates the distribution of motivations to consume legal drugs within the group of undergraduate students

\begin{tabular}{clc}
\hline \multicolumn{1}{c}{ Motivation } & \multicolumn{1}{c}{ Origin } & Frequency \\
\hline External Motivations: & Family. & 7 \\
& Means of communication. & 3 \\
& Friends. & 5 \\
& Personal characteristics. & 6 \\
& Need to belong. & 8 \\
Internal Motivations: & Curiosity. & 6 \\
& Pleasure. & 3 \\
& Idleness. & 2 \\
\hline
\end{tabular}


The following list refers to the variables found in the students' statements for each kind of motivation:

\section{External Motivations}

- Family: Use at home. Problems, conflicts, dysfunction or disintegration;

- Means of Communication: Advertising, leads to a superficial life. Its use is fashionable, and makes the substance look attractive;

- Friends: Influence of group style. Inclusion, acceptance "rules". Model to be imitated by its "members".

Internal Motivations

- Personal Characteristics: General Problems. Low self-esteem. Complexes, phobias. Loneliness. Need to hide or forget something. Lack of definitions;

- Need of belonging: Integration. Acceptance. Imitation;

- Curiosity: Curiosity itself. In order to know what it feels like doing it, trying it;

- Pleasure: Entertainment. Desire to be happy;

- Idleness.

\section{DISCUSSION AND CONCLUSION}

Undergraduate student's conceptions on motivation

This topic revealed that students are identifying only one kind of motivation, highlighting the external kind, which literature describes as being caused by an environmental agent and which generally disappears when the objective is reached, giving less importance to its results ${ }^{(14)}$.

According to this point of view, the proposal of the theory based on Social Motivation can be recovered: since motivation is based on the social influence of certain motives, the motives of others should be perceived and accepted as if they were our own, so that a motivated action or decision can be discussed. The influence of others does not need to be perceived as a low motive ${ }^{(8)}$.

Nevertheless, if the motivation is externally conceived for the situation under analysis, group influence on motivation should be discussed, as people try to meet at least part of their needs, cooperating with others in a group. In this group, each member contributes something and depends on the others to meet his aspirations. In this process, people often lose something of their individual personality and develop a group complex ${ }^{(15)}$. Thus, the second analysis category can be referred to:

Undergraduate student's conceptions on motives for consumption

The undergraduate students' results allowed for the evaluation and support of what Sinclair described once as the three kinds of motivation ${ }^{(16)}$ :

- As a consequence of the necessity state the person is in (addiction);

- As a consequence of the past events that led the person to achieve his objectives (frustration or family problems);

- As a consequence of a purpose, to achieve something (acceptance in a group of friends).

As mentioned since the introduction of this study, our students are consumers; and considering that the problem is serious and the implemented actions did not achieve the results expected until date, it would be better to focus on the solutions available to solve the problem.

This is an ambitious but possible objective, which can be achieved by setting feasible aims and working in an inter and multi-disciplinary way. Moreover, training should be promoted in emerging areas and problems that have been identified in the population, continuously demanding stronger and more solid steps until the common objectives are achieved.

In this context, besides the qualities of the qualitative research method, the study considers that the whole basis provided during the online specialization course on research about the drugs' phenomenon will help to achieve this ambitious objective.

\section{ACKNOWLEDGEMENTS}

Acknowledgements to the Inter-American Drug Abuse Control Commission/CICAD of the SubSecretary of Multidimensional Security at the Organization of American States/OAS, the Brazilian 
Anti-Drugs Secretary/SENAD, faculty members at the University of São Paulo at Ribeirão Preto College of Nursing, WHO Collaborating Centre for Nursing Research Development, Brazil, to the population who participated in the studies and to the representatives from eight Latin-American countries who participated in the I and II On-Line Specialization Program for Research Capacity-Building on the Drugs Phenomenon-PREINVEST, offered in 2005/2006 by the University of São Paulo at Ribeirão Preto College of Nursing, as a distance education course.

\section{REFERENCES}

1. Romani O. Las Drogas, Sueños y Razones. Barcelona: Ariel; 2004.

2. Medina NMO, Rebolledo EAO, Pedrão LJ. El significado de drogas para el estudiante de enfermería según el modelo de creencias de salud de Rosenstock. Rev Latino-am Enfermagem 2004 março; 12(número especial):316-23.

3. Belsasso G, Estañol B, Juárez-Jiménez H. Nuevas estrategias en el tratamiento farmacológico del tabaquismo. México: Consejo Nacional contra las Adicciones, 2001.

4. Gerada C, Ashworth M. ABC of mental health: addiction and dependence - I: illicit drugs. Br Med Assoc 1997 August; 2(315): 297-300.

5. Donoso JA. Drogas y universidad. La Estrella de Arica [seriado en línea]. 2003 Oct [consultado 2005 Dez 5]; 27 (10.051): [sobre 3 p.]. Disponible en: http:// www.estrellaarica.cl/site/edic/20031009004210/pags/ 20031009004818.html

6. Instituto Nacional de Estadística, Geografía e Informática (INEGI). Encuesta Nacional de Adicciones ENA-1998,2002 y 2003. México: Instituto Nacional de Estadística; 2004.

7. Luque R, Villagran JM. Psicopatologia descritiva: nuevas tendencias. Madrid (España): Editorial Trotta; 2000.

8. Nieto MJ, Abad MMA. Psicología para ciencias de la salud, estudio del comportamiento humano ante la enfermedad. Madrid (España): McGraw-Hill/Interamericana; 2004.

9. Tazón AP. Ciencias psicosociales. Barcelona (España): Masson; 1996.

10. Hernández R, Fernandez C, Batista P. Metodología de la Investigación. México: McGarw-Hill; 2003.

11. Burns NG. Investigación en Enfermería. Madrid (España): Elsevier; 2004.

12. Morant N. Social representations of gender in the media: quantitative and qualitative content analysis. In: Miell D, Wetherell M (editors). Doing Social Psychology. London: Sage; 1998.

13. Muría PN, Jaramillo EL. La complementariedad etnográfica. Investigación cualitativa. Una guía para abordar estudios sociales. Colombia: Kinesis; 2000.

14. Bigge M. Teorías del aprendizaje para maestros. México: Trillas; 1979.
15. Dessler G. Organización y administración, enfoque situacional. México: PHH SA.; 1979.

16. Sinclair H, Fawcett J. Al tschu's, psychology for nurses. London: Bailliére Tindall; 1991. 